\title{
TEMPAT PENYIMPANAN PERLENGKAPAN PEMBUATAN PIN
}

\author{
Darius Shyafary \\ Staf Pengajar Program Studi Desain Produk, Jurusan Desain \\ Politeknik Negeri Samarinda \\ Email: dariusshyafari@gmail.com \\ Merlinda Wahyuni \\ Mahasiswa Program Studi Desain Produk, Jurusan Desain \\ Politeknik Negeri Samarinda
}

\begin{abstract}
Abstrak
Di era yang serba modern ini, kebanyakan masyarakat membutuhkan benda-benda yang berguna bagi rutinitas sehari-hari mereka dan sebagai alat komunikasi yang biasanya berupa tanda pengenal maupun souvenir. Salah satu tanda pengenal dan souvenir yang paling sering digunakan oleh masyarakat adalah berupa pin dan gantungan kunci. Bahan pembuat pin dan gantungan kunci yang tergolong banyak dengan ukuran yang beragam sudah selayaknya memiliki tempat penyimpanan khusus yang dapat digunakan selain untuk menyimpan perlengkapan pembuat pin, tetapi juga digunakan agar dapat melindungi dari kerusakan dan tidak berserakan disembarang tempat. Namun, dari hasil pengamatan ke beberapa media percetakan yang ada di Samarinda salah satunya di Mabes O2, diketahui bahwa tempat penyimpanan perlengkapan pin yang mereka gunakan saat ini hanya berupa kertas plastik yang ditumpuk dalam suatu kardus atau box plastik sehingga menyebabkan perlengkapan bahan pembuatan pin tersebut menjadi mudah sekali tercampur. Dalam laporan dengan judul "Tempat Penyimpanan Perlengkapan Pembuatan Pin" ini telah memberikan alternatif baru dalam pengembangan desain tempat penyimpanan perlengkapan pembuatan pin. Tujuan dari proyek ini adalah mendesain sebuah produk berinovasi yang memudahkan dan mempercepat pengguna dalam proses produksi finishing pin atau gantungan kunci. Dengan menggunakan metode yang sudah dilakukan yaitu diantaranya: pengumpulan data lapangan, analisis, alternatif desain, pengembangan alternatif desain terpilih dan final desain, sehingga dihasilkan desain tempat penyimpanan perlengkapan pembuatan pin yang memiliki konsep gaya desain minimalis modern.
\end{abstract}

Kata Kunci: Tanda Pengenal, Pin, Penyimpanan, Minimalis, Modern 
Vol. 5, No. 2, April 2018

\section{abstract}

In this modern era, most people need objects that are useful for their daily routine and as a means of communication that usually form of identification or souvenir. One of the most common identification and souvenirs used by the public is the pins and key chains. Pick-knitting materials and key chains that belong to many diverse sizes should have a special storage area that can be used in addition to storing pin fixtures, but also used to protect from damage and not scattered anywhere. However, from the observation of some printing media in Samarinda one of them in Mabes O2, it is known that the storage of pin equipment that they use today is only a plastic paper stacked in a cardboard box or plastic so that the equipment makes the pin making material becomes very easy to mix. In a report entitled "Storage Place of Pin Making Equipment" has provided a new alternative in the development of pin storage equipment design. The purpose of this project is to design an innovate product that facilitates and accelerates the user in the production process of finishing pin or key chain. By using the methods that have been done are: field data collection, analysis, alternative design, development of selected design alternatives and final design, so that the design produced the storage equipment pin that has the concept of modern minimalist design style.

Keywords: ID Card, Pin, Storage, Minimalist, Modern

\section{Latar Belakang}

Souvenir adalah suatu benda yang identik dengan suatu event atau sebagai penanda suatu daerah tertentu, yang pada umumnya berbentuk ringkas, mungil serta memiliki nilai artistik. Ada banyak sekali jenis souvenir yang sering kita temui ,salah satunya yaitu souvenir jenis Pin. Pin merupakan benda berbentuk lingkaran, kotak, bintang (apapun) yang memiliki gambar di bagian depan dan pengait (peniti) yang menempel di belakangnya. Kebutuhan akan souvenir ini cocok untuk instansi, kantor, perusahaan, organisasi, dan lain-lain. Pin tidak hanya berfungsi sebagai aksesoris, tetapi saat ini banyak jenis pin yang bisa kita jumpai di pasaran, ada pin unt uk gantungan kunci, souvenir acara bahkan dalam beberapa kelompok atau organisasi di masyarakat kita sering menjumpai pin digunakan sebagai penanda keanggotaan seseorang dalam organisasi atau sebuah kelompok (Firmansyah,2016).

Oleh karena dalam suatu event kebutuhan dan permintaan pembuatan sebuah pin semakin meningkat, maka kebutuhan akan tempat penyimpanan pembuatan pin juga menjadi hal yang penting. Tempat penyimpanan ini selain digunakan untuk menyimpan perlengkapan pembuat pin, tetapi juga digunakan agar dapat melindungi dari kerusakan dan tidak berserakan disembarang tempat.

Salah satu media percetakan di Samarinda, Kalimantan Timur yang melayani pembuatan pin dalam jumlah banyak dan juga merupakan sponsor dalam proyek pembuatan tempat penyimpanan perlengkapan pembuatan pin ini adalah media percetakan Mabes $\mathrm{O} 2$ yang bertempat di $\mathrm{Jl}$. Pemuda IV. Mabes O2 berdiri sejak tanggal 17 Agustus 2009 sebagai tempat pengembangan jasa produksi pembuatan berbagai aneka merchandise (hadiah perusahaan) yang biasa dijadikan sebagai keperluan promosi, branding ataupun sebagai gift yang ditujukan untuk meningkatkan usaha dalam sebuah industri ataupun pengingat kenangan dalam suatu event tertentu.

Namun, dari hasil pengamatan dan wawancara di Mabes $\mathrm{O} 2$ dan ke beberapa tempat percetakan tempat produksi pin yang ada di Samarinda diketahui bahwa 
belum terdapatnya tempat penyimpanan khusus untuk perlengkapan pembuatan pin yang memenuhi syarat-syarat tempat penyimpanan yang baik. Hasil pengamatan menyatakan bahwa tempat penyimpanan pin yang ada saat ini hanya berupa kertas plastik yang ditumpuk dalam suatu kardus atau box plastik sehingga menyebabkan perlengkapan bahan pembuatan pin tersebut menjadi mudah sekali tercampur. Perlengkapan pin yang terbilang cukup banyak jenis dan ukurannya yang beragam sudah seharusnya memiliki tempat penyimpanan khusus yang memiliki ruang-ruang tertentu sehingga memudahkan dalam proses produksi pin tersebut.

Masalah inilah yang membuat munculnya inovasi untuk menciptakan suatu produk yang berfungsi sebagai wadah pelindung dan wadah penyimpan yang memiliki ruang-ruang tertentu sebagai tempat pemisah antara jenis bahan pin dan ukuran pin yang beragam serta dapat menyatukan antara bahan dan alat press pin dalam satu tempat.

\section{Metode Desain}

Dalam mendesain untuk memberikan arah agar proses desain terstruktur menggunakan metode parancangan dari Rosnani Ginting (2010) dengan langkah-langkah sebagai berikut.

\subsection{Pemrograman.}

Pemrograman adalah perintah dalam membuat rancangan yang mengikuti langkah-langkah demi menyelesaikan permasalahan yang ada di lingkungan produk yang akan di desain dan memilih permasalahan yang akan diselesaikan sebagai tujuan akhir dari perancangan produk.

\subsection{Pengumpulan Data}

Pengumpulan data adalah teknik atau cara-cara yang dapat digunakan untuk mengumpulkan data. Literatur dan wawancara dapat menambah informasi mengenai keadaan lapangan dan mengetahui lebih jelas kebutuhan pengguna untuk tempat penyimpanan perlengkapan pembuatan pin. Dengan demikian, data yang dikumpulkan bersifat baik dan benar.

\subsection{Analisis}

Analisis dilakukan terhadap pemasalahan, data dan informasi yang telah tekumpul dan mencari kekurangan dan kelebihan yang ada pada produk tempat penyimpanan perlengkapan pembuatan pin yang sudah ada. Analisa ini dilakukan untuk perancangan produk guna memberikan petunjuk mengenai produk apa yang dibutuhkan oleh pengguna.

\subsection{Sintesis}

Sintesis di sini mengaju ke konsep dari "Tempat Penyimpanan Perlengkapan Pembuatan Pin" ini yang mana produk tersebut berpacu pada tempat percetakan yang melayani pembuatan pin. Merancang atau mendesain tempat penyimpanan ini dibuat dengan efisien menyesuaikan ruang tempat finishing, menciptakan tempat penyimpanan yang ergonomis, fungsional serta dapat digunakan dalam jangka waktu yang lama sesuai dengan kebutuhan pengguna.

\subsection{Pengembangan}

Pengembangan ini merupakan pengembangan dari analisis dan sintesis yang mampu menjadi produk yang maksimal. Pengembangan di sini dilakukan sebagai penyempurnaan produk yang maksimal dalam menyelesaikan masalah dan memenuhi kebutuhan pengguna.

\subsection{Komunikasi}

Komunikasi merupakan proses desain yang dimana proses tersebut melewati beberapa langkah meliputi: 1) Gambar Alternatif, 2) Gambar Terpilih, 3) Pengembangan Desain, 4) Hasil Akhir, dan 5) Final 
Vol. 5, No. 2, April 2018

III. Pembahasan

\subsection{Analisis Pasar}

Analisis pasar dilakukan agar produsen dapat menganalisa dan menentukan peluang-peluang pasar yang dapat ditembus sehingga akan mendapatan sasaran konsumen yang tepat. Analisis pasar mencakup lokasi atau letak dipasarkannya suatu produk, misalnya seberapa luas ruang lingkup pasar, strategi atau lokasi yang dipilih terhadap sasaran konsumen maupun terhadap sasaran distributor produk, serta perusahaan pesaing yang mungkin memasarkan produk yang sama.

Dalam melakukan analisis pasar, dilakukan pendekatan-pendekatan untuk menentukan sasaran konsumen. Berikut adalah pendekatan-pendekatan yang dilakukan :

\section{Segmentasi Geografis}

Menurut hasil segmentasi geografis, target pasar produk ini ditujukan kepada media percetakan Mabes O2, sehingga segmentasi ini tertuju untuk wilayah yang ada di Samarinda yang terletak di Jl. Pemuda IV.

\section{Segmentasi Demografis}

Menurut hasil segmentasi demografis, target pasar produk tempat penyimpanan perlengkapan pembuatan pin ini dibagi berdasarkan usia dan tingkat sosial seseorang. Menurut tingkatan usia, produk ini ditujukan untuk pengguna dengan gender pria yang berusia 20-40 tahun dan dengan tingkat sosial menengah ke atas menyesuaikan dengan mayoritas tenaga kerja yang ada di Mabes O2.

\section{Segmentasi Psikografis}

Menurut hasil segmentasi psikografis, produk ini ditujukan kepada percetakan Mabes O2, karena percetakan ini melayani pembuatan pin dengan jumlah banyak, sehingga kebutuhan akan tempat penyimpanan perlengkapan pembuatan pin menjadi sangat dibutuhkan.
Segmentasi Perilaku

Menurut hasil segmentasi perilaku, tempat penyimpanan perlengkapan pembuatan pin ini dirancang dengan memperhatikan variabel ukuran skat atau ruang tempat penyimpanannya. Seperti tempat penyimpanan bahan pengolah pin yang dibuat dengan ukuran yang menyesuaikan kapasitas maksimal penampungan bahan yang ingin disimpan dan dengan tempat peletakan mesin press yang dibuat menyesuaikan dengan ukuran dua mesin press yang ada di Mabes $\mathrm{O} 2$.

\subsection{Analisis Ergonomi dan Antropome- tri}

Analisis ergonomi dilakukan untuk meminimalkan resiko terjadinya kecelakaan dalam bekerja serta memberikan kenyamanan pada produk yang dirancang. Dengan demikian efisiensi kesehatan, keselamatan dan kenyamanan dalam melakukan kegiatan menggunakan produk tersebut dapat dilakukan secara maksimal. Sedangkan analisis antropometri dilakukan guna mendapatkan dimensi atau ukuran produk yang sesuai dengan tubuh pengguna. Hasil dari nalisis ergonomi dan anthropometri didapat data sebagai berikut:

Untuk menentukan panjang dari produk tempat penyimpanan perlengkapan pembuatan pin ini, antropometri yang digunakan adalah jarak bentang dari ujung jari tangan kanan ke kiri. Gender yang digunakan adalah pria dengan kelompok 50\% persentile dan dengan nilai dimensi $165 \mathrm{~cm}$. Ukuran tersebut adalah ukuran maksimum, sehingga panjang tempat penyimpanan perlengkapan pembuatan pin saat dalam keadaan tertutup adalah $90 \mathrm{~cm}$ dengan pembagian ukuran $40 \mathrm{~cm}$ untuk panjang lemari penyimpanan alat press dan $50 \mathrm{~cm}$ untuk panjang laci penyimpanan bahan baku pin, sehingga panjang keseluruhan tempat penyimpanan pada saat laci disamping kiri ditarik secara menyeluruh adalah $140 \mathrm{~cm}$. 
Untuk menentukan lebar dari produk tempat penyimpanan perlengkapan pembuatan pin ini, antropometri yang digunakan adalah jarak genggaman tangan ke punggung pada posisi tangan ke depan. Gender yang digunakan adalah pria dengan kelompok $50 \%$ persentile dan dengan nilai dimensi $70 \mathrm{~cm}$. Ukuran tersebut adalah ukuran maksimum, sehingga lebar atau tingkat kedalaman produk tempat penyimpanan perlengkapan pembuatan pin ini adalah 50 $\mathrm{cm}$.

Untuk menentukan tinggi dari produk tempat penyimpanan perlengkapan pembuatan pin ini, antropometri yang digunakan adalah tinggi bahu pada posisi berdiri tegak. Gender yang digunakan adalah pria dengan kelompok $5 \%$ persentile dan dengan nilai dimensi $130 \mathrm{~cm}$. Ukuran ini adalah ukuran maksimum, sehingga panjang tempat penyimpanan perlengkapan pembuatan pin adalah $120 \mathrm{~cm}$.

Untuk menentukan tinggi dan peletakan handle pada bagian laci bawah tempat penyimpanan perlengkapan pembuatan pin agar mudah untuk dijangkau adalah menggunakan antropometri tinggi bahu pada posisi jongkok. Gender yang digunakan adalah pria dengan kelompok $5 \%$ persentile dan dengan nilai dimensi adalah $70 \mathrm{~cm}$. Ukuran tersebut adalah ukuran maksimum. Sehingga tinggi dan letak handle laci pada bagian bawah diukur dari lantai keatas adalah $12 \mathrm{~cm}$ dari lantai.

Untuk menentukan lebar handle tempat penyimpanan perlengkapan pembuatan pin ini, antropometri yang digunakan adalah dimensi lebar tangan pria dewasa. Gender yang digunakan adalah pria dengan kelompok $95 \%$ persentile agar dapat digunakan oleh semua gender. Nilai dimensi kelompok tersebut adalah $9 \mathrm{~cm}$ dengan tambahan toleransi $10 \mathrm{~cm}$ untuk asumsi sarung tangan. Ukuran tersebut adalah ukuran maksimum. Sehingga lebar handle pada produk adalah $10 \mathrm{~cm}$.

\subsection{Analisis Konfigurasi}

Analisis konfigurasi yang dilakukan untuk mendapatkan susunan atau konfigurasi dari tiap-tiap komponen yang terdapat pada Tempat Penyimpanan Perlengkapan Pembuatan Pin. Berikut adalah gambaran dari konfigurasi produk berserta isinya. Dari beberapa alternatif konfigurasi yang telah dilaksanakan, terpilih alternatif konfigurasi seperti yang ditunjuukan dalam gambar 1 .

Pada alternatif konfigurasi dalam gambar 1, kelebihannya adalah terletak pada peletakan mesin press dan moulding pin yang tersusun rapi pada satu lemari sehingga memudahkan dalam mengambil atau mencari serta mempercepat dalam proses produksi. Sedangkan, kelemahannya adalah pada tempat peletakan moulding yang terlalu besar sehingga banyak space yang tidak terisi. Komponen rak moulding dan rak penyimpanan mesin press pin yang terdapat pada satu lemari dengan satu pintu dan juga terdapat laci penyimpanan seng dan plastik pin serta laci penyimpanan bahan cermin dan kertas cetak. Dari analisis konfigurasi tersebut diketahui bagian komponen yang memerlukan sistem adalah pada bagian : Bingkai atau dinding produk, Laci penyimpanan seng pin, plastik pin, cermin gantungan kunci dan kertas cetak, dan bagian pintu lemari. 
Vol. 5, No. 2, April 2018

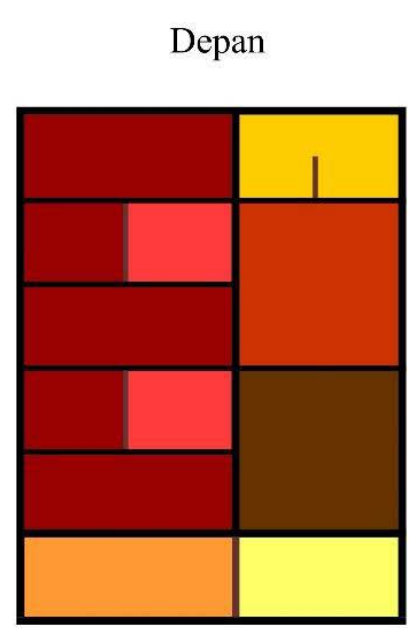

Skala $: 1: 10$

\section{Samping \\ Kanan}
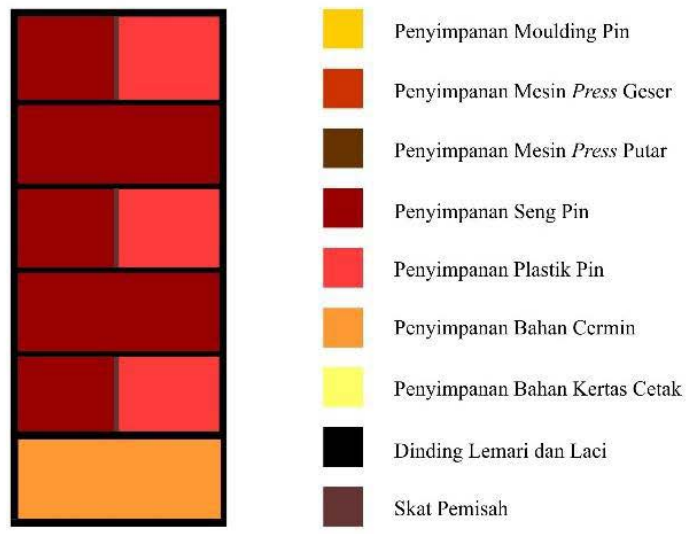

Gambar 1. Alternatif konfigurasi terpilih

\subsection{Analisis Sistem}

Analisis sistem dilakukan untuk mengetahui sistem apa saja yang sesuai untuk diterapkan pada setiap komponen produk tempat penyimpanan perlengkapan pembuatan pin ini adalah dengan melakukan pendekatan berdasarkan jenis sistem atau sifat kontruksinya. Kriteria sistem kontruksi yang diperlukan adalah sistem yang memiliki tingkat kemudahan dalam penyambungan dan pemasangan pen atau purus penyambung, memiliki sambungan dengan kekuatan struktur yang kuat dan kokoh serta sesuai dengan konsep yang diinginkan yaitu dengan konsep produk yang digunakan untuk tidak dipindah-pindah.

Dari hasil analisis jenis dan sifat kontruksi sistem yang telah dilakukan, nilai paling besar dihasilkan oleh sistem kontruksi permanen, sehingga sistem kontruksi inilah yang akan diterapkan pada semua bagian komponen yang terdapat pada produk tempat penyimpanan perlengkapan pembuatan pin ini.

Dari hasil sistem sambungan kayu yang telah dilakukan, nilai paling besar dihasilkan oleh sistem sambung Square Ended Butt Joints dan Rabbet Joints, sehingga sistem sambung inilah yang akan diterapkan pada bagian dinding dan skat pada produk tempat penyimpanan perlengkapan pembuatan pin ini.

Setelah diketahui sambungan yang akan digunakan, selanjutnya perlu dilakukan analisis mengenai hardwares dan accesories rel laci yang akan digunakan pada kontruksi laci tempat penyimpanan seng, plastik, cermin dan kertas cetak pada produk tempat ini. Kriteria yang diperlukan pada hardwares dan accesories dalam kontruksi rel laci ini adalah rel laci yang memiliki harga yang tidak terlalu mahal, dengan kekuatan struktur material yang kuat dan kokoh dalam menahan beban muatan yang terdapat pada laci dan dengan tingkat kemudahan pemasangan yang lebih cepat dan praktis. Berikut tabel hardwares dan accesories rel laci yang akan diaplikasikan ke produk tempat penyimpanan berdasarkan kriteria yang telah ditentukan.

Dari hasil analisis pemilihan rel laci diatas, terpilihlah rel laci terbuat dari logam sebagai hardwares dan accesories sistem geser pada setiap laci yang terdapat pada produk tempat penyimpanan perlengkapan pembuatan pin ini. Sedangkan untuk sistem geser pada bagian pintu lemari adalah menggunakan sistem sleding door yai- 
tu dengan pembuatan jalur rel (railing) dan pemasangan roda pada sisi bawah dan atas pintu.

\subsection{Analisis Material}

Analisis material dilakukan untuk menentukan material yang baik dan tepat untuk digunakan pada produk, sehingga nantinya akan menghasilkan produk yang aman dan nyaman dengan kegiatan pengguna (user). Pada proyek pembuatan produk ini sistem material body yang digunakan adalah metode furniture tanpa rangka dengan kriteria material yang diinginkan adalah material yang memiliki ketebalan 1,5 $\mathrm{cm}$, dengan harga yang tidak terlalu mahal, memiliki kontruksi yang cukup kuat untuk menahan beban mesin press pin yang berbobot diatas $7 \mathrm{~kg}$ dan memiliki daya tahan terhadap air yang baik serta mudah untuk ditemukan di toko-toko bangunan khususnya toko bangunan yang ada di kota Samarinda.

Dari hasil analisis material yang telah dilakukan, nilai paling besar dihasilkan oleh material kayu olahan multipleks, sehingga material inilah yang akan dipilih menjadi salah satu material utama untuk membuat produk tempat penyimpanan perlengkapan pembuatan pin khususnya pada kontruksi rangka datar (bingkai datar) pada produk tersebut dan dengan tambahan material pendukung berupa busa general dan kain satin untuk bagian pelindung dalam laci tempat penyimpanan cermin gantungan kunci.

Sedangkan untuk tahap finishing, kriteria yang diinginkan adalah material finishing yang memiliki harga tidak terlalu mahal, yang mudah dalam pengerjaannya, dengan proses pengerjaan yang lebih cepat dan menghasilkan finishing dengan warna yang tajam, mencolok, memberikan tampilan yang mewah dan menarik. Dari hasil analisis material finishing yang telah dilakukan, nilai paling besar dihasilkan oleh material finishing dengan HPL, karena material ini lebih praktis untuk diterapkan pada produk dan tidak memerlukan waktu yang lama dalam pengerjaannya sehingga untuk semua bagian body pada produk tempat penyimpanan ini akan menggunakan material finishing dengan HPL. Namun, ada bagian tertentu yang mengharuskan penggunaan finishing dengan menggunakan cat duco, yaitu pada bagian handle dan cerukan yang terdapat pada laci-laci tempat menyimpan seng dan plastik pin. Bagian yang berukuran kecil ini tidak memerlukan waktu yang terlalu lama dalam masa pengeringannya sehingga memungkinkan untuk menggunakan material finishing dengan cat duco ini.

\subsection{Analisis Bentuk}

Proses pembuatan pin yang mengharuskan pengerjaan yang cepat dan tanggap, sehingga konsep pemilihan gaya desain yang diinginkan pada produk ini adalah gaya desain yang terkesan simple, mudah dioperasionalkan, dan tanpa ornamen yang berlebihan.

Ciri gaya desain Futurisme yang memberikan kesan dinamis (bergerak) kurang efektif untuk diaplikasikan pada produk tempat penyimpanan ini karena produk ini tidak untuk dipindah - pindah, sedangkan untuk gaya desain Art Deco yang masih terikat dengan motif-motif generik dan geometris seni Asia Timur sehingga tidak sesuai dengan konsep desain yang diinginkan. Untuk gaya desain Bauhaus sebenarnya sudah memenuhi ciri-ciri konsep gaya desain yang diinginkan namun dari hasil pendekatan gaya desain, gaya minimalis modern adalah gaya dengan kesederhanaan bentuk yang trendy, simple, stylish, up-todate dan penggunaannya yang serba cepat, praktis serta efisien sehingga sesuai dengan penggunaan operasional produk di tempat percetakan pin yang selalu dikejar oleh dateline dalam pengerjaannya, khususnya di Mabes O2 yang merupakan sponsor dari proyek pembuatan tempat penyimpanan ini. Hal ini menjadikan alasan kenapa gaya desain ini lebih cocok untuk diaplikasikan 
Vol. 5, No. 2, April 2018

pada produk tersebut.

Sesuai dengan gaya desain yang akan diaplikasikan, produk ini dibuat dengan bentuk yang berkesan sederhana dan eksklusif dari segi bentuk dan tanpa pemberian ornamen yang berlebihan namun tetap mengutamakan segi fungsionalnya, sehingga produk dapat memenuhi kebutuhan dalam segi styling maupun fungsi dan operasionalnya.

\subsection{Analisis Warna}

Analisis warna sangat diperlukan untuk mendapatkan warna yang sesuai dengan konsep yang diinginkan. Adapun warna yang akan digunakan pada produk Tempat Penyimpanan Perlengkapan Pembuatan Pin ini adalah sebagai berikut :

Dari analisis warna yang telah dilakukan warna merah, putih dan kuning adalah warna yang akan diaplikasikan pada pewarnaan produk tempat penyimpanan perlengkapan pembuatan pin ini. Analisis warna ini dilakukan dalam dua jenis, yaitu untuk warna yang mendominasi dan warna yang digunakan sebagai aksentuasi.

Warna pendominasi yang akan diaplikasikan pada produk yaitu warna merah dan putih, karena warna merah merupakan palet warna brand dari sponsor pada proyek pembuatan produk ini dan juga warna merah memiliki aura yang kuat, memberi arti gairah dan memberi energi untuk menyerukan terlaksananya suatu kegiatan atau pekerjaan sehingga hal ini bisa memberikan semangat kepada orang yang melihatnya, namun pengaplikasian warna merah yang berlebihan bisa memberikan dampak negatif karena auranya yang terlalu kuat dan terkesan hangat sehingga ditambahkan warna dominasi putih yang dijadikan sebagai penyimbang warna, karena kesan yang diberikan warna ini terkesan ringan, menyejukan dan dapat menampilkan dan menekankan warna lain yang disandingkan dengannya. Sedangkan warna aksentuasi yang akan diaplikasikan adalah warna kuning, karena warna ini memiliki daya tarik yang kuat, mampu merangsang pandangan mata dan dapat meningkatkan aktifitas mental.

\subsection{Pengembangan Desain \\ Desain awal}

Tahap awal dalam mendesain adalah membuat sketsa-sketsa awal desain. Selanjutnya sketsa-sketsa desain awal tersebut dianalisis untuk dipilih sesuai kriteria yang telah ditentukan. Dari beberapa sketsa awal, setelah dianalisis terpilih sketsa seperti yang ditunjukkan seperti dalam gambar 2. Alternative sketsa awal dalam gambar 2 ini telah memenuhi konsep desain yang diinginkan, yaitu sebuah produk yang berbentuk simple sehingga tidak terlalu banyak menggunakan dan membuang bahan, serta dengan konsep gaya desain modern minimalis menyesuaikan dengan target user yang mayoritasnya terdiri dari laki-laki dewasa.

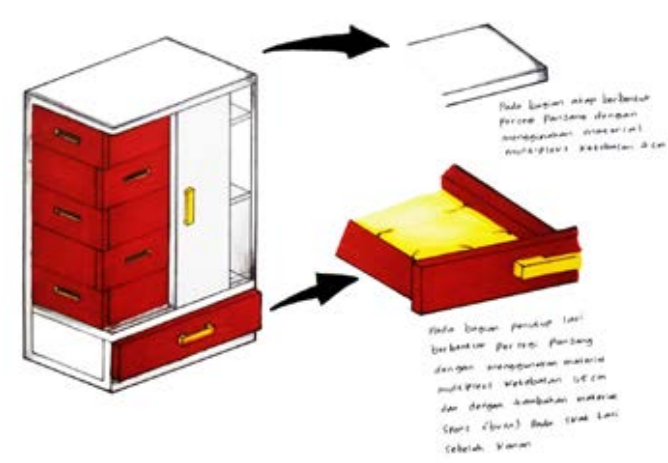

Gambar 2. Alternatif desain awal terpilih 
Pengembangan Alternatif Desain Terpilih

Selanjutnya desain awal tadi dikembangkan lagi menjadi beberapa alternatif desain, yang dianalisis sesuia ktiteria yang telah ditentukan, sehingga terpilih alternatif desain pengembangan seperti ditunjukkan dalam gambar 3. Desain alternatif dalam gambar 3 ini menggunakan material handle (tarikan) tanam yang dapat memudahkan dalam menggeser pintu atau laci terutama pada penempatan di lokasi yang kurang luas atau sempit. Serta bentuk cerukan yang terdapat pada laci dengan dua arah berbeda memiliki bentuk kotak menyudut yang bisa memberikan petunjuk mengenai arah bukaan laci.

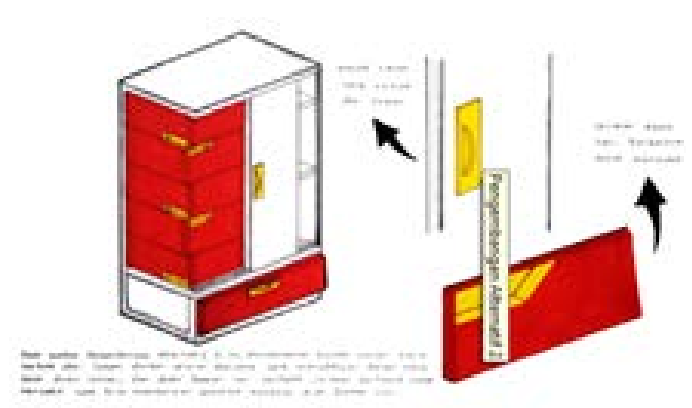

Gambar 3. Alternatif desain terpilih

\section{Desain Akhir}

Desain akhir adalah gambaran terakhir mengenai produk yang telah tercapai. Dimana desain akhir tersebut terbagi dalam beberapa gambar detail, antara lain adalah gambar 3D modeling, gambar teknik, dan foto prototipe. Berikut adalah desain akhir produk Tempat Penyimpanan Perlengkapan Pembuatan Pin :

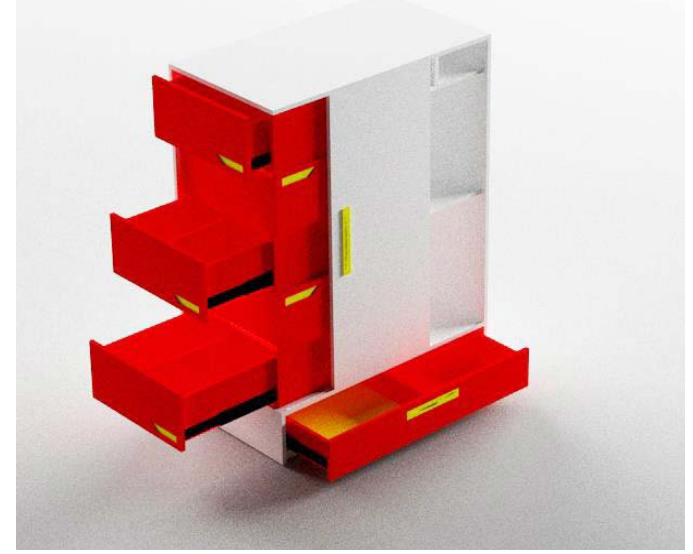

Gambar 4. Gambar Presentasi

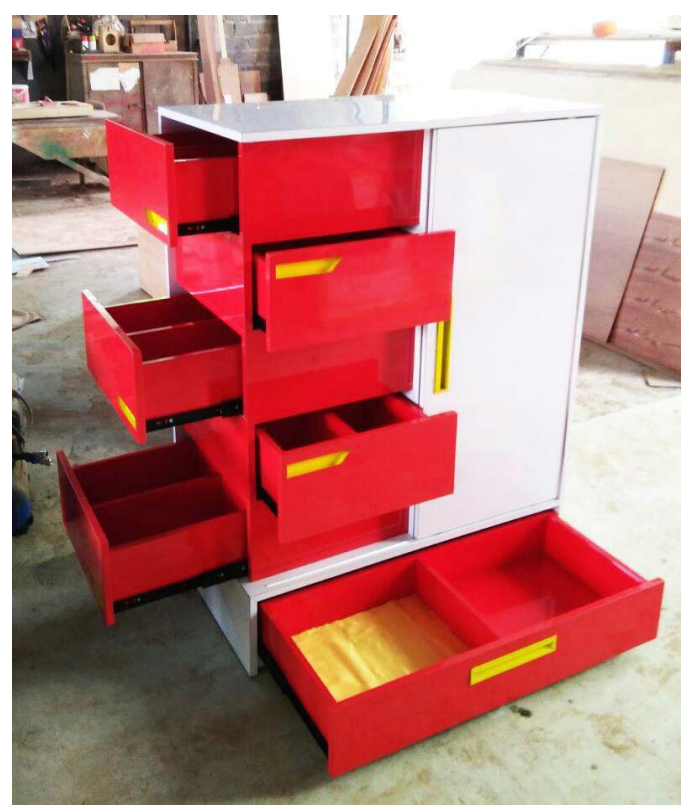

Gambar 5. Prototipe 
Vol. 5, No. 2, April 2018

\section{KESIMPULAN DAN SARAN}

Dari hasil perancangan "Tempat Penyimpanan Perlengkapan Pembuatan Pin", maka kesimpulan yang didapat ialah sebagai berikut :

Produk Tempat Penyimpanan Perlengkapan Pembuatan Pin yang dihasilkan memiliki fungsi yang dapat memudahkan pengguna dalam proses produksi pembuatan pin khususnya dalam hal finishing pin. Tempat Penyimpanan Perlengkapan Pembuatan Pin yang dihasilkan dapat digunakan sebagai wadah pelindung dan wadah penyimpan yang memiliki ruang-ruang tertentu sebagai tempat pemisah antara jenis bahan pin dan ukuran pin yang beragam serta dapat menyatukan antara bahan dan alat press pin dalam satu tempat.

Pada produk ini terdapat enam laci sebagai tempat peletakan bahan baku pembuat pin dan juga memiliki satu pintu lemari yang pada bagian dalamnya terdapat dua skat rak yang digunakan sebagai peletakan mesin press dan moulding pin. Pada bagian pintu ini menggunakan sistem sleding door. Warna yang diaplikasikan pada produk tempat penyimpanan ini yaitu menggunakan warna dominasi merah dan putih dengan tambahan aksentuasi dari warna kuning pada bagian handle dan bagian cerukan laci. Tempat Penyimpanan Perlengkapan Pembuatan Pin ini menggunakan gaya desain modern minimalis karena menyesuaikan dengan konsep desain yang mengharuskan pengerjaan yang cepat dan tanggap.
Desain perancangan "Tempat Penyimpanan Perlengkapan Pembuatan Pin" ini diharapkan kedepannya dapat diterima dan digunakan dengan baik oleh masyarakat khususnya para karyawan yang ada di Mabes O2, dengan penyesuaian yang dilakukan langsung di lapangan dari penyesuaian bentuk, dimensi dan warna produk, sehingga diharapkan agar dapat menjadi produk yang bisa diminati oleh konsumen. Analisis mengenai aktifitas konsumen yang berkaitan dengan produk yang dirancang juga dilakukan agar dapat memberikan nilai tambah produk tersebut karena kemungkinan kebutuhan konsumen telah terpenuhi. 


\section{DAFTAR PUSTAKA}

Akmal, Imelda, (2008), Seri Rumah Ide Edisi 5/III : Plafon Kreatif, Gramedisa Pustaka Utama, http://www.books.google.co.id, (06 Maret 2018)

Akmal, Imelda, (2013), Seri Rumah Ide-Cermin Interior, PT Gramedia Pustaka Utama, http://www.books.google.co.id, (28 Mei 2018)

Anggara, P. D., (2014), Pengaruh Jarak Screw Terhadap Kekuatan Sambungan Pada Baja Ringan, Universitas Negeri Surabaya, (01 Maret 2018)

Cahyadi, Dwi, (2014), Aplikasi Mannequin Pro untuk Desain Industri, LeutikaPrio, (26 November 2017)

Fauzi, Rosyid Hanif, (2009), Detail Produk Pin Magnet 58mm, http://www.books.google. co.id, (19 Februari 2018)

Firmansyah, Dito, (15 Juli 2016), Cara Membuat Pin Peniti dan Pin Gantungan Kunci, UD Wijaya, http://www.books.google.co.id, (03 Oktober 2017)

Ginting, Rosnani, (2010), Perancangan Produk, Graha Ilmu, http://www.books.google. co.id, (09 Januari 2018)

Kasali, Rhenald, (2007), Membidik Pasar Indonesia, PT Gramedia Pustaka Utama, (23 Oktober 2017)

Lenggosari, (2002), Paduan Warna Menarik Untuk Rumah, Griya Kreasi, http://www. books.google.co.id, (18 April 2018)

Lensuffie, Tikno, (2009), Mengenal Kontruksi Kayu untuk Furniture dan bangunan, Esensi Erlangga Group, http://www.books.google.co.id, (19 Februari 2018) 